\title{
PENGARUH EMOTIONAL FREEDOM TECHNIQUE (EFT) TERHADAP TINGKAT KECEMASAN PASIEN PRE PERCUTANEOUS CORONARY INTERVENTION (PCI) DI SMC RS TELOGOREJO
}

\author{
Aola Isnadiya* \\ Felicia Risca Ryandini** \\ Taufiq Priyo Utomo*** \\ *) Alumni Program Studi S.1 Ilmu Keperawatan STIKES Telogorejo Semarang, J1. Puri \\ Anjasmoro Raya, Tawangmas, Semarang Bar., Kota Semarang, Jawa Tengah 50144 \\ **) Dosen Program Studi S.1 Ilmu Keperawatan STIKES Telogorejo Semarang, Jl. Puri \\ Anjasmoro Raya, Tawangmas, Semarang Bar., Kota Semarang, Jawa Tengah 50144, \\ 08985848461, email: felicia_riska@stikestelogorejo.ac.id \\ ***) Dosen Pengampu Statistik STIKES Telogorejo Semarang, Jl. Puri Anjasmoro Raya, \\ Tawangmas, Semarang Bar., Kota Semarang, Jawa Tengah 50144
}

Corresponding Author: Felicia Risca Ryandini

\begin{abstract}
Abstrak
Penyakit Jantung Koroner (PJK) adalah gangguan fungsi jantung akibat otot jantung kekurangan darah karena adanya penyempitan pembuluh darah koroner. Salah satu tindakan invasif yang biasa dilakukan untuk menangani PJK adalah Percutaneous Coronary Intervention (PCI). Masalah yang sering muncul pada pasien pre PCI adalah kecemasan. Kecemasan tersebut harus ditangani, karena dapat mengganggu kondisi hemodinamik pasien menjadi tidak stabil. Salah satu upaya untuk mengatasai kecemasan adalah Emotional Freedom Technique (EFT). Penelitian ini bertujuan untuk mengetahui adanya pengaruh EFT terhadap kecemasan pasien yang akan menjalani PCI di SMC RS Telogorejo. Rancangan penelitian ini menggunakan quasi experiment dengan pendekatan one group pre-post test with control group. Jumlah sampel dalam penelitian ini adalah 24 responden yang terbagi menjadi 2 kelompok, sehingga 12 responden menjadi kelompok intervensi dan 12 responden menjadi kelompok kontrol dengan teknik pengambilan sampel menggunakan purposive sampling. Uji statistik yang digunakan adalah Paired T-Test untuk membandingkan nilai pre test dan post test pada masing-masing kelompok dan Independent T-Test digunakan untuk membandingkan selisih kecemasan antara kelompok intervensi dan kelompok kontrol. Hasil penelitian menunjukkan bahwa pemberian EFT memiliki pengaruh yang signifikan terhadap tingkat kecemasan pasien yang akan menjalani PCI dengan selisih skor 2.833 dan $p$-value $\leq 0.05$ (0.0001). Rekomendasi penelitian ini adalah supaya EFT dapat menjadi salah satu intervensi tambahan untuk mengatasi kecemasan pasien pre PCI.
\end{abstract}

Kata kunci: Penyakit Jantung Koroner, Kecemasan, Emotional Freedom Technique, Percutaneous Coronary Intervention

Isnadiya, A., Ryandini, F.R., \& Utomo, T.P. / Pengaruh emotional freedom technique...Hal 12 dari 57 
Jurnal IImu Keperawatan Medial Bedah 1 (2), Desember 2018, 1-57

ISSN 2338-2058 (print), ISSN 2621-2986 (online)

\section{PENDAHULUAN}

Penyakit jantung koroner (PJK) adalah istilah umum yang dipakai untuk semua gangguan yang menyangkut obstruksi aliran darah melalui arteri koronaria (Baradero, Mary \& Yakobus, 2008, hlm.1). Penyebab utama PJK adalah penyempitan arteri koronaria besar di bagian proksimal oleh aterosklerosis. Bila diameter lumen berkurang 60-70\% maka suplai O2 menuju jaringan akan terganggu (Stefan \& Lang, 2008, hlm.218).

Beragam teknik telah dikembangkan untuk membuka pembuluh darah dan mengembalikan darah melalui arteri koroner, salah satunya adalah Percutaneous Coronary Intervention (PCI). PCI atau biasa disebut Kateterisasi jantung adalah suatu tindakan invasif dimana satu atau lebih kateter dimasukkan ke jantung dan pembuluh darah tertentu (Smeltzer \& Bare, 2014, hlm. 743). Kateter dimasukkan melalui pembuluh perifer, biasanya femoral, lalu masuk ke ruang jantung. Saat ini PCI direkomendasikan karena merupakan sebuah prosedur invasif non operatif sehingga komplikasi dapat ditekan serendah-rendahnya (Wijaya \& Putri, 2013, hlm.12).

Data World Health Organization (WHO) tahun 2012 menunjukkan 17,5 juta orang di dunia meninggal akibat penyakit kardiovaskuler atau 31\% dari 56,5 juta kematian di seluruh dunia. Sedangkan data Riskesdas tahun 2013 menunjukkan, prevalensi tertinggi untuk penyakit kardiovaskuler di Indonesia adalah PJK, yakni sebesar 1,5\%. Sementara jumlah pasien yang menjalani PCI berdasarkan hasil studi pendahulan mengenai jumlah pasien baik PCI maupun PAC di SMC RS Telogorejo pada tahun 2016 sebanyak 273 pasien PCI, sedangkan pada tahun 2017 sebanyak 296 pasien yang menjalani PCI sekaligus PAC.

Jomansyah (2013, I23) mengungkapkan bahwa tindakan PCI dapat menyebabkan komplikasi berupa infark miokardium, stroke, aritmia dan kematian. Hal tersebut menyebabkan seseorang merasa terancam. Stuart (2008, hlm.175) menyampaikan bahwa keadaan seseorang merasa dirinya terancam tersebut dapat menimbulkan efek kecemasan (ansietas). Kecemasasan dapat berespon pada sistem kardiovaskuler. antara lain gangguan hemodinamik seperti palpitasi, jantung berdebar-debar, peningkatan tekanan darah, penurunan tekanan darah penurunan denyut nadi dan pingsan (Stuart 2008, hlm.114 \& 174). Padahal kondisi hemodinamika yang stabil 
Jurnal Ilmu Keperawatan Medial Bedah 1 (2), Desember 2018, 1-57

ISSN 2338-2058 (print), ISSN 2621-2986 (online)

menjadi salah satu persiapan pasien sebelum dilakukan tindakan PCI karena keadaan hemodinamika yang tidak stabil akibat kecemasan tentu akan mengganggu kelancaran proses PCI yang akan dilakukan (Aziz, 2011, I14). Agar tidak mengganggu kelancaran PCI, dibutuhkan sebuah tindakan yang dapat mengatasi kecemasan pasien pre PCI. Salah satu tindakan tersebut adalah Emotional Freedom Technique (EFT).

EFT merupakan salah satu teknik terapi yang cukup sering digunakan dalam praktik psikologi. Selain mudah dipelajari, EFT juga praktis untuk digunakan pada diri sendiri. Tujuan EFT biasanya mencakup memaksimalkan potensi pribadi, menghilangkan rasa nyeri dan menghilangkan perasaan negatif yang berlebih seperti kecemasan (Setengah, 2016, hlm. 87). Hal tersebut sesuai dengan penelitian yang dilakukan oleh Shari, WW., Suryani dan Etika, E. (2014) dengan judul Emotional freedom techniques dan tingkat kecemasan pasien yang akan menjalani Percutaneous Coronary Intervention menunjukkan terdapat perbedaan yang bermakna terhadap tingkat kecemasan sebelum dan sesudah dilakukan terapi EFT $(\mathrm{p}=<0,05)$.

\section{METODE PENELITIAN}

Penelitian ini menggunakan rancangan quasi experiment dengan pendekatan one group pre-post test with control group. Dimana penelitian ini membagi responden menjadi dua kelompok yaitu kelompok intervensi dan kontrol. Pada kelompok intervensi diberikan tindakan EFT dan diukur tingkat kecemasan pre test dan post test. Sementara pada kelompok kontrol hanya diukur tingkat kecemasan pre test dan post test kemudian membandingkan tingkat kecemasan pada kedua kelompok tersebut.

Penelitian ini bertujuan untuk mengetahui adanya pengaruh EFT terhadap kecemasan pasien yang akan menjalani PCI di SMC RS Telogorejo. Besar sampel yaitu 24 responden yang kemudian dibagi menjadi 2 kelompok, sehingga terdapat 12 responden kelompok intervensi dan 12 responden kelompok kontrol. Teknik pengambilan sampel menggunakan purposive sampling dengan cara dimana responden yang dijumpai terlebih dahulu masuk kedalam kelompok intervensi dan responden yang dijumpai selanjutnya masuk kelompok kontrol dan berseling seterusnya.

Penelitian ini menggunakan uji Paired T-Test untuk membandingkan nilai pre test dan post test pada masing-masing kelompok dan Independent T-Test digunakan untuk membandingkan selisih kecemasan antara kelompok intervensi dan kontrol. Alat ukur yang digunakan dalam penelitian ini yaitu 
Jurnal IImu Keperawatan Medial Bedah 1 (2), Desember 2018, 1-57

ISSN 2338-2058 (print), ISSN 2621-2986 (online)

instrumen kecemasan Zung Self-Rating Anxiety Scale (ZSAS) dan berlangsung pada 14 Mei - 21 Mei 2018.

\section{HASIL DAN PEMBAHASAN}

\section{Karakteristik responden berdasarkan jenis kelamin, usia, pendidikan, dan pekerjaan}

Tabel 1

Gambaran Karakteristik Responden berdasarkan Jenis Kelamin, Usia, Pendidikan dan Pekerjaan di SMC RS Telogorejo pada Tanggal 14 Mei - 28 Mei $2018(n=24)$

\begin{tabular}{|c|c|c|c|c|c|}
\hline \multirow[t]{2}{*}{ No } & \multirow[t]{2}{*}{ Variabel } & \multicolumn{2}{|c|}{ Kelompok Intervensi } & \multicolumn{2}{|c|}{ Kelompok Kontrol } \\
\hline & & $\mathbf{F}$ & $\%$ & $\mathbf{F}$ & $\%$ \\
\hline \multirow[t]{4}{*}{1} & Jenis & & & & \\
\hline & kelamin & 6 & 50 & 7 & 58.3 \\
\hline & a. Laki-laki & 6 & 50 & 5 & 47.1 \\
\hline & $\begin{array}{l}\text { b. Perempu } \\
\text { an }\end{array}$ & & & & \\
\hline \multirow[t]{6}{*}{2} & Usia (tahun) & & & & \\
\hline & a. $35-45$ & 1 & 8.3 & 1 & 8.3 \\
\hline & b. $46-55$ & 2 & 16.7 & 1 & 8.3 \\
\hline & c. $56-65$ & 6 & 50 & 6 & 50 \\
\hline & d. $66-75$ & 2 & 16.7 & 4 & 33.3 \\
\hline & e. $76-85$ & 1 & 8.3 & 0 & 0 \\
\hline \multirow[t]{5}{*}{3} & Pendidikan & & & & \\
\hline & a. SD & 0 & 0 & 1 & 8.3 \\
\hline & b. SMP & 3 & 25.0 & 0 & 0 \\
\hline & c. SMA & 8 & 66.7 & 8 & 66.7 \\
\hline & d. PT & 1 & 8.3 & 3 & 25.0 \\
\hline \multirow[t]{4}{*}{4} & Pekerjaan & & & & \\
\hline & a. Bekerja & 5 & 41.7 & 3 & 25.0 \\
\hline & $\begin{array}{l}\text { b. Tidak } \\
\text { bekerja }\end{array}$ & 7 & 58.3 & 9 & 75.0 \\
\hline & Total & 12 & 100 & $\begin{array}{l}1 \\
2\end{array}$ & 100 \\
\hline
\end{tabular}

Berdasarkan tabel 1 dapat diketahui pada kedua kelompok bahwa jenis kelamin responden terbanyak adalah laki-laki (54.1\%) dengan usia terbanyak adalah 56-65 tahun (50\%), tingkat pendidikan responden paling banyak yaitu SMA (66.7\%) dengan pekerjaan terbanyak pada kedua kelompok yakni tidak bekerja (66.7\%). Isnadiya, A., Ryandini, F.R., \& Utomo, T.P. / Pengaruh emotional freedom technique...Hal 15 dari 57 
Jurnal Ilmu Keperawatan Medial Bedah 1 (2), Desember 2018, 1-57

ISSN 2338-2058 (print), ISSN 2621-2986 (online)

\section{Jenis Kelamin}

Black dan Hawks (2009, hlm.84) mengungkapkan bahwa pria memiliki risiko yang lebih tinggi mengalami serangan jantung karena pria tidak memiliki proteksi hormon estrogen seperti wanita yang membuat kadar kolesterol lebih baik dan pembuluh darah jadi lebih lentur.

Penelitian Wulandari Dyah (2009) juga menyebutkan terdapat hubungan antara jenis kelamin dengan kejadian PJK ( $\mathrm{p}=0,008)$. Sementara penelitian dari Zahrawardani, Herlambang dan Anggraheny (2013) mengenai jumlah pasien PJK berdasarkan jenis kelamin di RSUP Dr Kariadi Semarang didapatkan hasil analisis mayoritas sampel berjenis kelamin laki-laki yaitu sebanyak 88 pasien $(68,80 \%)$.

\section{Usia}

Usia responden terbanyak adalah 56-65 tahun yang artinya diatas 45 tahun. Hasil ini didukung oleh penelitian Donal Nababan (2008) di RSU Dr. Pirngadi Medan bahwa penderita PJK didapatkan lebih banyak pada kelompok usia $\geq 45$ tahun. Begitu juga dengan penelitian yang dilakukan Wulandari Dyah (2009) yang menunjukkan adanya hubungan antara usia dengan kejadian PJK ( $\mathrm{p}=0,003)$ di poli jantung RS Muhammadiyah Palembang.

Kowalak (2013, hlm.170) dan Lemone (2016, hlm.1146) menyebutkan bahwa usia merupakan faktor risiko PJK dimana penambahan usia akan meningkatkan risiko terjadinya PJK. Semakin tua usia maka semakin berkurangnya fungsi organ yang optimal. Salah satunya adalah pembuluh darah dan otot jantung yang tidak lagi elastis. Penempelan plak yang mengandung lemak dan jaringan fibrosa secara progresif membuat lumen arteri koronaria makin sempit sehingga volume darah yang mengalir melalui arteri tersebut berkurang.

\section{Pendidikan}

Hasil penelitian menunjukkan tingkat pendidikan responden terbanyak pada kedua kelompok yaitu SMA sejumlah 16 dari 24 responden. Hal tersebut didukung oleh penelitian yang dilakukan Damayanti (2017) di RSI Sultan gung Semarang dengan hasil didapatkan bahwa jumlah responden dengan PJK terbanyak adalah berpendidikan SMA (63\%).

Kuraesin (2009, I6) menyampaikan bahwa tingkat pendidikan individu berpengaruh terhadap kemampuan berpikir. Semakin tinggi tingkat pendidikan maka individu semakin mudah berpikir Isnadiya, A., Ryandini, F.R., \& Utomo, T.P. / Pengaruh emotional freedom technique...Hal 16 dari 57 
Jurnal Ilmu Keperawatan Medial Bedah 1 (2), Desember 2018, 1-57

ISSN 2338-2058 (print), ISSN 2621-2986 (online)

rasional dan menangkap informasi baru. Kemampuan analisis akan mempermudah individu dalam menguraikan masalah baru.

\section{Pekerjaan}

Pekerjaan responden terbanyak pada kedua kelompok yakni tidak bekerja. Hasil ini berbeda dengan penelitian yang dilakukan oleh Salim dan Nurrohmah (2013) yang mendapatkan hasil bahwa penderita PJK mayoritas adalah masih bekerja, sementara yang tidak bekerja hanya 31 responden dari 60 sampel yang digunakan.

Hasil beberapa penelitian menunjukkan bahwa pekerjaan bukanlah menjadi faktor dari PJK. Adapun hasil yang peneliti dapatkan bahwa sebagian besar responden tidak bekerja berhubungan dengan usia responden yang sebagian besar menginjak lansia dan telah pensiun atau berhenti dari kerja. Responden yang tidak bekerja akan cenderung minim dalam melakukan aktivitas fisik.

Lemone (2016, hlm.1146) menyebutkan kurangnya aktivitas fisik ini yang meningkatkan faktor risiko PJK pada responden karena lemak terus tersimpan dalam tubuh dan tidak terjadi pemecahan menjadi energi, lemak yang tersimpan dalam tubuh, menempati rongga-rongga tubuh terutama pembuluh darah sehingga terjadi plak dan arterosklerosis.

\section{Gambaran tingkat kecemasan pre test dan post test dalam data numerik}

Tabel 2

Gambaran Skor Kecemasan Responden Pre Test dan Post Test Pada Kelompok Intervensi dan Kelompok Kontrol di SMC RS Telogorejo pada Tanggal $14 \mathrm{Mei}-28$ Mei $2018(n=24)$

\begin{tabular}{ccccc}
\hline & \multicolumn{3}{c}{ Kelompok } \\
\hline & Intervensi & \multicolumn{2}{c}{ Kontrol } \\
\hline & Pre & Post & Pre & Post \\
\hline Mean & 13.50 & 10.50 & 12.92 & 12.75 \\
\hline Median & 13.50 & 10.50 & 12.50 & 12.50 \\
\hline Maksimum & 16 & 14 & 16 & 16 \\
\hline Minimum & 12 & 9 & 11 & 11 \\
\hline
\end{tabular}

Berdasarkan tabel 2 dapat diketahui bahwa skor kecemasan tertinggi pada kedua kelompok yaitu 16 dan terjadi penurunan pada kelompok intervensi menjadi 14. Nilai rata-rata 
Jurnal Ilmu Keperawatan Medial Bedah 1 (2), Desember 2018, 1-57

ISSN 2338-2058 (print), ISSN 2621-2986 (online)

skor kecemasan pada pasien kelompok intervensi pre test post test menurun 3.00 sementara kelompok kontrol mengalami penurunan 0.169 .

\section{Gambaran Tingkat Kecemasan Pre Test dan Post Test dalam Data Kategorik}

Tabel 3

Gambaran Kategori Kecemasan Responden Pre Test dan Post Test pada Kelompok Intervensi dan Kelompok Kontrol di SMC RS Telogorejo pada Tanggal 14 Mei- 28 Mei 2018 ( $n=24)$

\begin{tabular}{lcccccc}
\hline \multirow{2}{*}{ Kelompok } & \multicolumn{6}{c}{ Tingkat Kecemasan } \\
\cline { 2 - 7 } & \multicolumn{2}{c}{ Ringan } & \multicolumn{2}{c}{ Sedang } & \multicolumn{2}{c}{ Berat } \\
\cline { 2 - 7 } & F & \% & F & \% & F & \% \\
\hline Intervensi & & & & & & 16.7 \\
Pre & 3 & 25.0 & 7 & 58.3 & 2 & 0 \\
Post & 11 & 91.7 & 1 & 8.3 & 0 & 16.7 \\
\hline Kontrol & & & & & & 16.7 \\
Pre & 6 & 50.0 & 4 & 33.3 & 2 & 2 \\
Post & 6 & 50.0 & 4 & 33.3 & 2 & \\
\hline
\end{tabular}

Berdasarkan tabel 3 dapat dilihat bahwa terjadi perubahan kecemasan pada kelompok intervensi dari ringan 3 (25\%), sedang 7 (58.3\%) dan berat 2 (16.7) menjadi ringan $11(91.7 \%)$, sedang $1(8.3 \%)$ dan berat 0 . Sementara pada kelompok kontrol tidak mengalami perubahan kecemasan, yaitu ringan $6(50 \%)$, sedang 4 (33.3\%) dan berat (16.7\%).

\section{Uji Normalitas Data}

Tabel 4

Hasil Uji Normalitas Data Responden Pre Test dan Post Test pada Kelompok Intervensi dan Kelompok Kontrol di SMC RS Telogorejo pada Tanggal 14 Mei - 28 Mei $2018(n=24)$

\begin{tabular}{cc}
\hline Kelompok & $\boldsymbol{P}$ \\
\hline Intervensi & \\
\hline Pre test & 0.228 \\
Post test & 0.053 \\
\hline Kontrol & \\
\hline Pre test & 0.288 \\
Post test & 0.134 \\
\hline
\end{tabular}

Uji normalitas data dilakukan menggunakan uji Shapiro Wilk karena $\mathrm{n} \leq 50$ dan didapatkan hasil $p$-value pada setiap kelompok yaitu $\geq 0.05$ yang menunjukkan data tersebut normal pada setiap kelompok intervensi dan kontrol baik pre test maupun post test. 
Jurnal IImu Keperawatan Medial Bedah 1 (2), Desember 2018, 1-57

ISSN 2338-2058 (print), ISSN 2621-2986 (online)

\section{Uji Homogenitas Varians}

Tabel 5

Hasil Uji Homogenitas Data Kecemasan Responden Pre Test Pada Kelompok Intervensi dan Kelompok Kontrol di SMC RS Telogorejo pada Tanggal $14 \mathrm{Mei}-28$ Mei 2018

\begin{tabular}{cc}
$n=24$ & $P$ \\
\hline Data & 0.437 \\
\hline Delompok intervensi dan kontrol & \\
\hline
\end{tabular}

Berdasarkan tabel 5 dapat disimpulkan bahwa hasil tes homogenitas yang dilakukan menggunakan Uji F didapatkan hasil yang homogen. Sehingga dapat ditarik kesimpulan bahwa semua data pre test baik pada kelompok intervensi maupun kontrol bermula dari skor kecemasan yang sama.

\section{Perubahan Nilai Rerata Kecemasan Pre Test dan Post Test pada Kelompok Intervensi}

Tabel 6

Penurunan Rerata Kecemasan Responden Pre Test dan Post Test pada Kelompok Intervensi di SMC RS Telogorejo pada Tanggal

14 Mei -28 Mei $2018(n=24)$

\begin{tabular}{cccc}
\hline Kecemasan & Rerata & Selisih & $\boldsymbol{P}$ \\
\hline Pre & 13.50 & \multirow{2}{*}{3.00} & 0.0001 \\
\hline Post & 10.50 & & \\
\hline
\end{tabular}

Berdasarkan tabel 6 didapatkan selisih penurunan kecemasan yaitu 3.00 dengan p-value $\leq 0.05(0.0001)$ yang artinya terdapat perbedaan yang signifikan antara rerata kecemasan pre dan post pada kelompok intervensi. 
Jurnal IImu Keperawatan Medial Bedah 1 (2), Desember 2018, 1-57

ISSN 2338-2058 (print), ISSN 2621-2986 (online)

\section{Perubahan Nilai Rerata Kecemasan Pre Test dan Post Test pada Kelompok Kontrol}

Tabel 7

Penurunan Rerata Kecemasan Responden Pre Test dan Post Test pada Kelompok Kontrol di SMC RS Telogorejo pada Tanggal

$$
\begin{gathered}
14 \mathrm{Mei}-28 \text { Mei } 2018 \\
n=24
\end{gathered}
$$

\begin{tabular}{cccc}
\hline Kecemasan & Rerata & Selisih & $\boldsymbol{P}$ \\
\cline { 1 - 2 } Pre & 12.92 & \multirow{2}{*}{0.169} & 0.166 \\
\cline { 1 - 2 } Post & 12.75 & & \\
\hline
\end{tabular}

Berdasarkan tabel 7 didapatkan selisih penurunan kecemasan yaitu 0.169 dengan p-value $>0.05(0.116)$ yang artinya tidak terdapat perbedaan yang signifikan antara rerata kecemasan pre dan post pada kelompok kontrol.

\section{Perbedaan Penurunan Kecemasan Antara Kelompok Intervensi dan Kelompok Kontrol}

Tabel 8

Perbedaan Penurunan Kecemasan Responden pada Kelompok Intervensi Dan Kelompok Kontrol di SMC RS Telogorejo pada Tanggal

14 Mei - 28 Mei 2018

$$
n=24
$$

\begin{tabular}{ccccc}
\hline Data & $\begin{array}{c}\text { Selisih Kelompok } \\
\text { Intervensi }\end{array}$ & $\begin{array}{c}\text { Selisih Kelompok } \\
\text { Kontrol }\end{array}$ & $\begin{array}{c}\text { Jumlah } \\
\text { Selisih }\end{array}$ & $\boldsymbol{P}$ \\
\hline Pre test dan post test & 3.00 & 0.169 & 2.381 & 0.0001 \\
\hline
\end{tabular}

Hasil uji Independent T-Test pada perbedaan kecemasan responden yang diberikan Emotional Freedom Technique (EFT) dengan yang tidak diberikan Emotional Freedom Technique (EFT) didapatkan selisih penurunan kecemasan yaitu 2.831 dengan p-value 0.0001 $(<0.05)$ yang artinya Ha diterima dan dapat disimpulkan bahwa ada perbedaan yang signifikan terhadap kecemasan pasien yang diberikan Emotional Freedom Technique (EFT) dengan yang tidak diberikan Emotional Freedom Technique (EFT). Nilai tersebut menunjukkan bahwa terdapat pengaruh yang signifikan pemberian Emotional Freedom Technique (EFT) terhadap tingkat kecemasan pasien pre Percutaneous Coronary Intervention (PCI) di SMC RS Telogorejo. 
Jurnal Ilmu Keperawatan Medial Bedah 1 (2), Desember 2018, 1-57

ISSN 2338-2058 (print), ISSN 2621-2986 (online)

Pada penelitian ini, kelompok intervensi diberikan salah satu teknik hipnoterapi yaitu Emotional Freedom Technique (EFT). Iskandar, (2010, hlm. 32) menjelaskan cara kerja Emotional Freedom Technique (EFT) yaitu menggunakan fikiran responden itu sendiri. Teknik ini adalah alat yang diterapkan berdasarkan teori yang menyatakan bahwa emosi yang berlebihan pada dasarnya bersifat negatif. Untuk membebaskan berbagai faktor emosional itu, EFT memberikan metode penyembuhan yang disebut set up yaitu ucapan kata afirmasi dan tapping yaitu dengan cara mengetuk-ngetuk titik-titik energi meridian tubuh.

Ucapan afirmasi adalah kalimat positif dan sugesti yang dikatakan oleh pasien sehingga secara tidak langsung akan membuat responden menjadi lebih yakin dan percaya akan kekuatan dalam dirinya yang berasal dari Tuhan. Sementara tapping atau ketukan yang dilakukan secara lembut akan membuat responden menjadi rileks (Setengah, 2016, hlm. 87).

Campuran dari keduanya yaitu afirmasi dan tapping menjadikan responden merasa lebih tenang sehingga mengakibatkan rangsangan ke hipotalamus untuk menurunkan produksi CRF (Cortictropin Releasing Factor) yang selanjutnya akan merangsang kelenjar pituitary anterior untuk menurunkan produksi ACTH (Adreno Cortico Tropin Hormon), hormon ini yang akan merangsang kortek adrenal untuk menurunkan sekresi kortisol yang akan menekan kerja sistem imun tubuh sehingga mengurangi tingkat kecemasan dan perlahan akan membebaskan emosi yang berlebihan (Vitale, 2008, hlm. 93).

Hasil perbandingan kedua kelompok tersebut menunjukkan bahwa kecemasan kelompok yang diberikan intervensi dapat menurun dibandingkan kelompok yang tidak diberikan intervensi. Hal tersebut terjadi karena pemberian EFT dapat mempengaruhi keadaan fisiologis responden dengan hasil akhir penurunan kecemasan yang dibuktikan dengan hasil analisa yang signifikan, sementara pada kelompok kontrol hanya dapat mempengaruhi keadaan psikis yaitu bertambahnya pengetahuan akan tetapi tidak dapat dibuktikan dengan hasil analisa yang signifikan.

Isnadiya, A., Ryandini, F.R., \& Utomo, T.P. / Pengaruh emotional freedom technique...Hal 21 dari 57 
Jurnal IImu Keperawatan Medial Bedah 1 (2), Desember 2018, 1-57

ISSN 2338-2058 (print), ISSN 2621-2986 (online)

\section{KESIMPULAN}

\section{Simpulan}

1. Karakteristik jenis kelamin responden terbanyak adalah laki-laki dengan usia responden terbanyak adalah 56-65 tahun. Tingkat pendidikan responden terbanyak yaitu SMA dan tidak bekerja.

2. Selisih kecemasan pre test dan post test responden kelompok intervensi diperoleh $p$-value $\leq 0.05(0.0001)$ yang artinya terdapat perbedaan yang signifikan antara pre test dan post test kelompok intervensi dengan penurunan rerata kecemasan yakni 3.00.

3. Selisih kecemasan pre test dan post test responden kelompok kontrol diperoleh $p$-value $>0.05$ (0.116) yang artinya tidak terdapat perbedaan yang signifikan antara pre test dan post test kelompok kontrol dengan penurunan rerata kecemasan yakni 0.169.

4. Perbedaan kecemasan kelompok intervensi dan kontrol yaitu 2.831 dan didapatkan p-value $0.0001(<0.05)$. Sehingga dapat ditarik kesimpulan bahwa ada pengaruh yang signifikan pemberian EFT terhadap tingkat kecemasan pasien pre PCI di SMC RS Telogorejo.

\section{Saran}

1. Bagi Pelayanan Kesehatan

Hasil penelitian ini dapat dijadikan salah satu intervensi tambahan pada pasien yang mengalami kecemasan sebelum tindakan Percutaneous Coronary Intervention (PCI).

\section{Bagi Institusi Pendidikan}

Hasil penelitian ini dapat dijadikan sebagai bahan bacaan untuk mahasiswa mengenai metode pemberian Emotional Freedom Technique (EFT) terhadap kecemasan pasien pre Percutaneous Coronary Intervention (PCI).

\section{Bagi Peneliti Selanjutnya}

Hasil penelitian ini dapat dijadikan sebagai informasi bagi peneliti selanjutnya yang akan meneliti tentang Emotional Freedom Technique (EFT) dengan mengamati adanya faktor perancu misal usia dan lingkungan serta dapat menyempurnakan kuesioner peneliti dengan melakukan uji validitas ulang menggunakan r-tabel. 
Jurnal IImu Keperawatan Medial Bedah 1 (2), Desember 2018, 1-57

ISSN 2338-2058 (print), ISSN 2621-2986 (online)

\section{DAFTAR PUSTAKA}

Andra, Saferi Wijaya dan Yessie Mariza Putri. (2013). Keperawatan medikal bedah (keperawatan dewasa).Yogyakarta: Nuha Medika.

Aziz, Abdul. (2011). Askep pre PCI (percutaneous coronary interventi on). https://www.scribd.co m/docu ment/54110035/Askep-Pre-PCI. Diunduh tanggal 11 Januari 2018.

Baradero, Mary., Mary,W.D dan Yakobus, S. (2008). Seri asuhan keperawatan klien gangguan kardiovaskular. Jakarta: EGC.

Black, J. M. dan Hawks, J. H. (2009). Keperawatan medikal bedah edisi 8 buku 3. Penerjemah Joko Mulyanto et, al. Singapore: Elsevier.

Dalami, E., Suliswati., Farida., Rochimah dan Banon. (2009). Asuhan keperawatan jiwa dengan masalah psikososial. Jakarta: Trans Info Media.

Damayanti, Hikmah Rizky. (2017). Hubungan tingkat pendidikan dan pengetahuan terhadap kepatuhan diit rendah kolesterol pada pasien penyakit jantung koroner di RSI Sultan Agung Semarang. http://repository.unissula.ac.id/7373/. Diunduh pada tanggal 23 Mei 2018.

Jomansyah M.U.A. (2013). Angiografi koroner. http://www.kalbemed. com/Portals/6/23_207TeknikAngiografi\%20Koroner.pdf. diperoleh tanggal 7 Januari 2018.

Kowalak, Jenifer P. (2013). Buku saku patofisiologi. Alih bahasa Andry Hartono. Jakarta: EGC

Kuraesin. (2009). Faktor-faktor yang mempengaruhi kecemasan pada pasien yang akan menghadapi operasi di RSUP Fatmawati. http://repository.uinjkt.ac.id/dspace/bitstream/123456789/2324/1/NYI\%20DEWI\%20KU RAESIN-FKIK.pdf. Diperoleh tanggal 7 Februari 2018.

Lemone, P., Karen, M dan Bauldoff, G. (2016). Buku ajar keperawtan medikal bedah. Alih bahasa Ayu Linda. Jakarta: EGC.

Nababan, Donal. (2008). Faktor risiko yang berhubungan dengan kejadian PJK di RSU Dr. Pirngadi Medan http://repository. usu.ac.id/889/2/ BAB\%20I.pdf. Diperoleh pada tanggal 24 Mei 2018.

Isnadiya, A., Ryandini, F.R., \& Utomo, T.P. / Pengaruh emotional freedom technique...Hal 23 dari 57 
Jurnal Ilmu Keperawatan Medial Bedah 1 (2), Desember 2018, 1-57

ISSN 2338-2058 (print), ISSN 2621-2986 (online)

Salim \& Nurrohmah. (2013). Hubungan olahraga dengan kejadian penyakit jantung koroner di RSUD dr. Moewardi. http://journal.ums.ac.id /sju/index.php/ujph.. diperoleh tanggal 23 Mei 2018.

Setengah, Obee. (2016). Hipnosis Go. Jakarta: Bintang Wahyu. https://books.google.co.id/books?id=At51DQAAQBAJ\&printsec=frontcover\&dq=hipnos is+go\&hl=id\&sa=X\&ved=0ahUKEwiImbf_kc_YAhXKVLwKHRa4A8MQ6AEIKDAA \#v=onepage \&q=eft\&f=false. Diperoleh tanggal 11 Januari 2018.

Shari, WW., Suryani dan Etika, E. (2014). Emotional freedom techniques dan tingkat kecemasan pasien yang akan menjalani percutaneous coronary intervention jkp.fkep. unpad.ac.id/index.php/jkp/article/download/83/79. Diunduh tanggal 15 Oktober 2017.

Silbernagl, Stefan dan Florian Lang. (2007). Teks \& atlas berwarna patofisiologi. Alih bahasa Iwan Setiawan dan Iqbal Mochtar. Jakarta: EGC.

Smeltzer, C S dan Bare, B G. (2001). Buku ajar keperawatan medical bedah Brunner \& Suddarth, alih bahasa Agung Waluyo, et al. Jakarta: EGC.

Stuart, G.W. (2007). Buku saku keperawatan jiwa. Alih bahasa Ramona P. Kapoh dan Egi Komara Yudha. Jakarta: EGC.

Wulandari, Dyah. Analisis faktor risiko kejadian penyakit jantung koroner di RSUP dr. Kariadi. https://jurnal.unimus.ac.id/index.php/kedokteran/article/down load/1341/1396. Diperoleh tanggal. 29 April 2018.

Zahrawardani, Herlambang dan Anggraheny. (2013). Analisis faktor risiko kejadian penyakit jantung koroner di rsup dr kariadi semarang. 1341-2791-1-SM.pdf. diunduh tanggal 22 Mei 2018.

Isnadiya, A., Ryandini, F.R., \& Utomo, T.P. / Pengaruh emotional freedom technique...Hal 24 dari 57 